\title{
Alternative method of sowing canola hybrids using adhesive tape ${ }^{1}$
}

\author{
Raissa Macedo Assis ${ }^{2 *}$ (D, Carla Gomes Machado², Simério Carlos Silva Cruz ${ }^{2}$, Givanildo Zildo da Siva², \\ Magno Gonçalves Braz ${ }^{2}$, Ingrid Maressa Hungria de Lima e Silva ${ }^{2}$
}

$10.1590 / 0034-737 X 201966060009$

\begin{abstract}
Canola, which has tiny oil-producing seeds, requires care during planting, so that there is an ideal number of plants. The aim of this study is to evaluate alternative method of sowing using adhesive tape and the influence it has on the emergence and vigor of the seedlings of different canola hybrids and define the best positioning of the adhesive tape for the formation of the experimental field. The study was carried out at the Seed Laboratory at the Universidade Federal de Goiás. The tests were conducted with hybrid canola seeds (Hyola: 50, 61, 433, 571CL and 575CL). The seed characterization was performed in terms of physiological quality. They were then sown: without adhesive tape; seeds arranged on adhesive tape with the tape facing down, sideways and up, with a completely randomized experimental design, in a $5 \times 4$ factorial scheme. The evaluations were performed: emergence, speed of emergence index and first seedling emergence count in sand. The use of the adhesive tape did not interfere in the emergence of canola hybrids seedlings, with the Hyola 571CL characterized as having the best performance while the Hyola 50 and 61 had inferior performances.
\end{abstract}

Keywords: Brassica napus L. var oleifera; emergence; experimental field; vigor.

\section{INTRODUCTION}

Canola (Brassica napus L. var oleifera) is an oilseed belonging to the Brassicaceae family, developed by Canadians while genetically improving the conventional rapeseed (Tomm et al., 2009b). In the last 40 years its production has grown rapidly worldwide, from the sixth most-produced oilseed in the world to the second (USDA, 2017). It has been used in Europe since the 13th century for food purposes, and the processed oil contains an adequate ratio of erucic acid as well as a balance between essential omega fatty acids 3-6-9 (Süzer, 2015). In addition to the food industry, it is currently used in biodiesel production and the by-product of the oil extraction, bran, is a useful supplement for animals (Pavlista et al., 2011; De Mori et al., 2014).
In the South of Brazil, canola is planted as a winter crop, much like safrinha (a second crop) in the CenterWest of the country (Tomm, 2006; Melgarejo Arruá et al., 2014), guaranteeing its place as part of the crop rotation system that exists in Brazilian agriculture. Canola is cultivated in different types of soil, from sandy-loam to silty-clay, and this is a main reason for its good performance and profitability (Süzer, 2015).

According to Tomm et al. (2009a), the sowing stage of the canola crop requires special attention, in particular, the seed drill needs to be regulated in order to evenly distribute 40 seeds $/ \mathrm{m}^{2}$ and that the depth sown be uniform (one to two centimeters). When followed, this enables adequate plant population, allows for greater yield potential, compensates for insect damage and reduces the presence of weeds by rapidly covering the soil.

\footnotetext{
Submitted on December 24 th, 2018 and accepted on September $26^{\text {th }}, 2019$.

${ }^{1}$ This work is part of the first author master's dissertation.

${ }^{2}$ Universidade Federal de Goiás, Unidade Acadêmica Especial de Ciências Agrárias, Jataí, Goiás, Brazil. rmacedoassis@gmail.com; carlagomesmachado@gmail.com; simerio_cruz@yahoo.com.br; givanildozildo@gmail.com; magno_vb@hotmail.com; ingridm_hungria@hotmail.com

"Corresponding author: rmacedoassis@gmail.com
} 
In the field, the small size of the seed may be a hindrance. However, using a special disk kit to sow canola provides adequate population and productivity (Shahin \& Valiollah, 2009; Tomm et al., 2009b). Mechanical sowing is not typically used in research plantations, which tend to be seeded manually due to their smaller size. The small size of the fields makes it impossible to use seeders or even the appropriate tools and equipment suitable for this crop.

The use of adhesive tape is an alternative for this scope of research, based on the project called "tape-seed" developed by Mateus Marrafon Nicolosi. The purpose of the project is to help small farmers, mainly family farmers, which allows the placement of seeds with an ideal space between them (Nicolosi, 2016).

With this premise, adhesive tape can be a viable alternative for the canola crop at a research level, possibly reducing sowing time in the field as well as improving the control surrounding planting density and the establishment of an ideal standard. With this in mind, the objective of this study is to evaluate the alternative adhesive tape method for sowing and its influence on the emergence and vigor of seedlings of different canola hybrids and to define the best positioning of the adhesive tape for the formation of the experimental field.

\section{MATERIAL AND METHODS}

The study was conducted in the Seed Laboratory at the Universidade Federal de Goiás, Regional Jataí (UFG). The seed characterization of the canola hybrids, Hyola 50, Hyola 61, Hyola 433, Hyola 571CL and Hyola $575 \mathrm{CL}$, was carried out by the following determinations and evaluations:

Moisture content - was determined using the greenhouse method at $105 \pm 3{ }^{\circ} \mathrm{C}$ for $24 \mathrm{~h}$ with two subsamples of $300 \mathrm{~g}$ of seeds for each hybrid (Brazil, 2009).

Weight of one thousand seeds - weighed by a precision analytical balance $(0.001 \mathrm{~g})$, with eight subsamples of 100 seeds for each hybrid (Brazil, 2009).

Germination Test - conducted with eight replicates of 50 seeds for each hybrid, placed to germinate in plastic boxes called "gerbox" on blotting-paper, moistened with distilled water in the proportion of 2.5 times the paper's dry weight. The gerboxes were packed in plastic bags and kept in a germination chamber at a constant temperature of $20^{\circ} \mathrm{C}$. The counts were performed on the seventh day after the test, and the results were expressed as percentage of normal seedlings, percentage of abnormal seedlings and percentage of dead seeds (Brazil, 2009).

First germination count - Conducted in conjunction with the germination test, counting the normal seedlings after five days according to the Regulation for Seed Analysis - RAS (Brazil, 2009).
Electrical conductivity - Performed through the method proposed for canola by Milani et al. (2012), with four subsamples of 50 physically pure seeds, weighed to two decimal places $(0.01 \mathrm{~g})$. The seeds were then immersed in $25 \mathrm{~mL}$ of deionized water and kept in a BOD chamber at 25 ${ }^{\circ} \mathrm{C}$ for eight hours. After this period the electrical conductivity was determined by a conductivity meter, with the results expressed in $\mu \mathrm{Scm}^{-1} \mathrm{~g}^{-1}$ of seed.

Accelerated aging - The seeds were placed to age in a single layer on canvas in "gerbox" boxes containing 40 $\mathrm{mL}$ of water, closed with a plastic bag, kept at $42{ }^{\circ} \mathrm{C}$ for 24 hours. This was followed by the germination test, as previously described, with counting taking place on the fifth day after sowing. The moisture content of the seeds was determined after aging with the same procedure described previously (Vieira \& Carvalho, 1994; Brazil, 2009).

The experimental design was completely randomized (DIC). The data was submitted to the Shapiro Wilk normality test and was transformed when necessary by the formula $(x+1)^{1 / 2}$, followed by an analysis of variance. The averages were compared by the Tukey test, at $5 \%$ probability.

Subsequently the five hybrid seeds were subjected to four methods of seeding according to Figure 1: the control (seeding without adhesive tape); downwards facing (seeds arranged of the tape with the tape facing down); sideways (placing the seeds on the tape and positioning the tape facing sideways) and upwards facing (seeds arranged on the tape with the tape facing up), being used an adhesive tape of general use, with $28.00 \times 6.00 \mathrm{~mm}$ dimension.

The experimental design was completely randomized (DIC), in a $5 \times 4$ factorial scheme (five hybrids of canola and four sowing methods) with four replications.

The following evaluations were carried out:

Emergence of seedlings in sand - Conducted with four replicates of 50 seeds. The sand was sterilized in an oven at $200{ }^{\circ} \mathrm{C}$ for two hours (Brazil, 2009) and placed in plastic trays $(30.0 \times 22.0 \times 5.5 \mathrm{~cm})$. Initially $2 / 3$ of the trays were filled with sand and after the treatments were set up, another layer of sand was added, maintaining a depth of approximately $1.5 \mathrm{~cm}$. A $60 \%$ water retention was calculated according to the recommendations by the RAS (Brazil, 2009). The wetting was carried out after sowing and the trays were packed in a plastic bag to maintain humidity. Afterwards the trays were kept in a germination chamber, at a constant temperature of $20{ }^{\circ} \mathrm{C}$. At the end, the emergence percentage was calculated based on normal seedlings. In addition, the seedlings were also classified as abnormal seedlings or dead seeds according to RAS (Brazil, 2009). 
The first emergence count of seedlings in sand Counting the percentage of normal seedlings that had emerged on the fifth day after sowing (Brazil, 2009).

Seedling speed of emergence index in sand (SEI) conducted concomitantly with the emergence test, the number of emerged seedlings with visible cotyledons were noted daily. At the end of the test, the data was submitted to the formula proposed by Maguire (1962).

The data was submitted to the Shapiro Wilk normality test, followed by analysis of variance. The averages were compared by the Tukey test, at $5 \%$ and $1 \%$ probability.

All analysis were performed in the Rbio statistical program (Bhering, 2017).

\section{RESULTS AND DISCUSSION}

In Table 1, the initial seed characterization of the canola hybrids revealed that there was similarity in the moisture content with values between $6.7 \%$ and $7.3 \%$. Considering that the initial water content is a key factor for the standardization of the evaluations to be performed later, the results ensure the credibility of the data obtained in the study. For the accelerated aging test, for example, in order not to compromise the results due to the differences in the speed of wetting and deterioration of the seeds during the test, it is recommended that the seed samples being compared do not show differences greater than $2 \%$ in the initial water content (Marcos Filho et al., 1999).

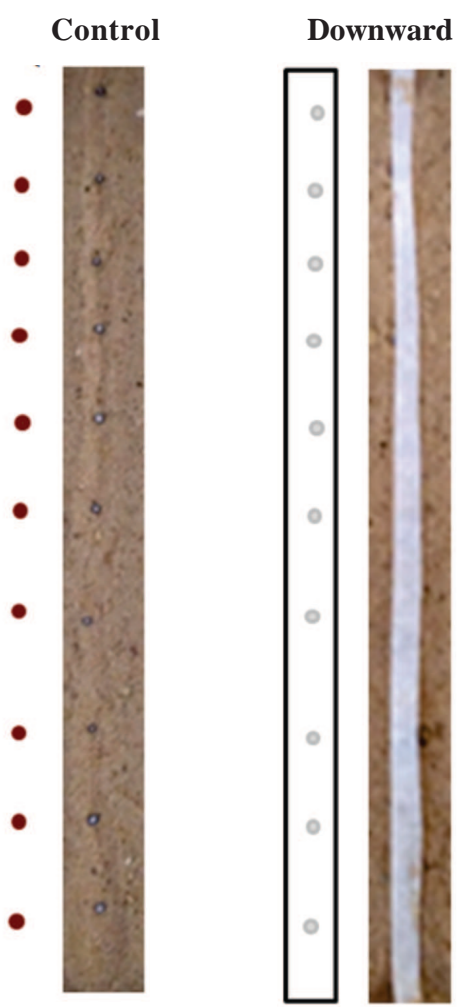

In Table 1, Hyola 50 and 433 hybrids obtained higher mass, $7.49 \mathrm{~g}$ and $7.39 \mathrm{~g}$, respectively, with intermediate results for germination and electrical conductivity. We can highlight the Hyola 571CL hybrid that, even with a lower mass, obtained the best germination (99\%) and vigor results evaluated by the first germination test (96\%), electrical conductivity $\left(94.2 \mu \mathrm{Scm}^{-1} \mathrm{~g}^{-1}\right)$ and accelerated aging (77\%), and therefore is referred to as the hybrid with seeds with a higher physiological potential.

The Hyola 61 seeds presented lower results for all variables, $81 \%$ germination, and a higher electrical conductivity of $226.0 \mu \mathrm{cm}^{-1} \mathrm{~g}^{-1}$, indicating a lower vigor. The electrical conductivity test is related to the reorganization capacity of the cell membrane system, the faster the reestablishment, the less the solutes release and the greater the seed vigor (Tillmann \& Menezes, 2012).

It is worth mentioning that the germination percentage of all the evaluated hybrids is above the marketing standard set for canola, which is $80 \%$ (Brazil, 2013).

Table 2 shows the analysis of variance of the variables of the data obtained in the emergence, first emergence count, speed of emergence index, abnormal seedlings and dead seeds of five canola hybrids using four sowing methods. There were significant interactions for all variables except for emergence and dead seeds, which had a significant effect only for the hybrid factor.
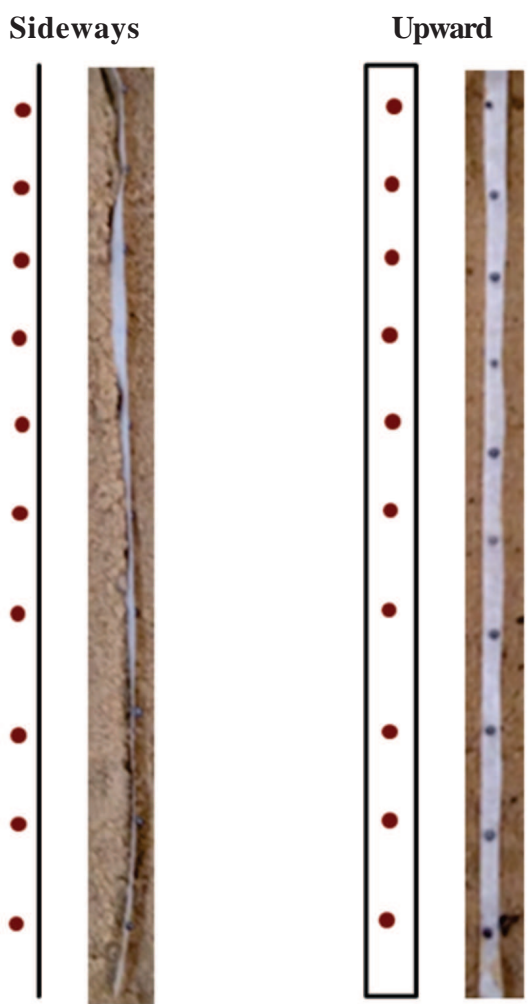

Figure 1: Alternative sowing method for five canola seed hybrids. 
The use of adhesive tape during sowing did not influence the emergence of the seedlings. The emergence percentage of canola seedlings of the different hybrids in sand was between $72 \%$ and $92 \%$ (Table 3). For the hybrid seed batches Hyola 401 and Hyola 60, Ávila (2005) observed emergence of between 73 and $95 \%$.

The hybrid Hyola 571CL presented the best performance, with $92 \%$ emergence, results compatible with the initial characterization (Table 1).

There was no difference in the seedling emergence of Hyola 433, 61 and 575CL hybrids, with the latter two not differing from Hyola 50. The high emergence of hybrid 571CL seedlings is probably due to this seed being more vigorous. The vigor is related to the biochemical aspects of the seeds and their resistance to suboptimal conditions, which include temperature, water availability, soil characteristics, plant protection and management practices (Marcos Filho, 2015). Venkatesh et al. (2014) did not find a significant difference when evaluating the effect of the seed tape on the emergence of corn seedlings under nursery conditions.

The percentage of abnormal seedlings (Table 4) varied from $3 \%$ to $18 \%$, depending on the hybrid and sowing method. Therefore, none of the evaluated sowing methods had an absence of abnormal seedlings for the evaluated hybrids. Hyola 571CL and 50 hybrids showed differences depending on the sowing method employed. In both, the percentage of abnormal seedlings was higher when sowed with the tape facing down, while Hyola 50 did not differ from those sown with the tape facing to the side.

Initial seedling performance is determined by the conversion of starch into sugars readily available for absorption in the resumption of embryonic growth. The greater the efficiency of this process and in the translocation of assimilates, the greater the seed vigor (Peske et al., 2012). As canola seeds are small, it should be considered that the energy reserve stored in the cotyledons is less (Koch et al., 2015), and in those sowing

Table 3: Emergence (\%) of Hyola 433, Hyola 61, Hyola 571CL, Hyola 575CL and Hyola 50 canola hybrids using an alternative sowing method

\begin{tabular}{lc}
\hline Hybrids & Emergence $(\%)$ \\
\hline Hyola 433 & $81 \mathrm{~b}$ \\
Hyola 61 & $76 \mathrm{bc}$ \\
Hyola 571CL & $92 \mathrm{a}$ \\
Hyola 575CL & $77 \mathrm{bc}$ \\
Hyola 50 & $72 \mathrm{c}$ \\
\hline
\end{tabular}

Means followed by the same letter do not differ statistically from each other according to the Tukey test at 0.01 probability.

Table 1: Moisture content (MC), mass of one thousand seeds (MTS), germination (G), abnormal seedlings (AS), dead seeds (DS), first germination count (FGC), electrical conductivity (EC), accelerated aging (AE) and moisture content after aging (MCA) of five canola hybrids ${ }^{1}$

\begin{tabular}{lccccccccc}
\hline $\begin{array}{l}\text { Hybrids } \\
\text { (Hyola) }\end{array}$ & $\begin{array}{l}\text { MC } \\
(\boldsymbol{\%})\end{array}$ & $\begin{array}{c}\text { MTS } \\
(\mathbf{g})\end{array}$ & $\begin{array}{c}\mathbf{G} \\
(\boldsymbol{\%})\end{array}$ & $\begin{array}{c}\mathbf{A S}^{\mathbf{2}} \\
(\boldsymbol{\%})\end{array}$ & $\begin{array}{c}\mathbf{D S}^{\mathbf{2}} \\
(\boldsymbol{\%})\end{array}$ & $\begin{array}{c}\text { FGC } \\
(\boldsymbol{\%})\end{array}$ & $\begin{array}{c}\text { EC } \\
\left(\mathbf{m S c m}^{-1} \mathbf{g}^{-1}\right)\end{array}$ & $\begin{array}{c}\text { AE } \\
(\boldsymbol{\%})\end{array}$ & $\begin{array}{c}\text { MCA } \\
(\boldsymbol{\%})\end{array}$ \\
\hline 50 & 7.0 & $7.49 \mathrm{a}$ & $92 \mathrm{~b}$ & $3 \mathrm{~b}$ & $5 \mathrm{~b}$ & $63 \mathrm{c}$ & $172.3 \mathrm{bc}$ & $64 \mathrm{ab}$ & 24.2 \\
61 & 7.2 & $5.33 \mathrm{c}$ & $81 \mathrm{c}$ & $7 \mathrm{c}$ & $12 \mathrm{c}$ & $60 \mathrm{~cd}$ & $226.0 \mathrm{~d}$ & $48 \mathrm{~b}$ & 22.6 \\
433 & 7.3 & $7.39 \mathrm{a}$ & $91 \mathrm{~b}$ & $3 \mathrm{~b}$ & $6 \mathrm{~b}$ & $50 \mathrm{~d}$ & $146.0 \mathrm{~b}$ & $68 \mathrm{ab}$ & 20.6 \\
$571 \mathrm{CL}$ & 6.7 & $5.45 \mathrm{c}$ & $99 \mathrm{a}$ & $0 \mathrm{a}$ & $1 \mathrm{a}$ & $96 \mathrm{a}$ & $94.2 \mathrm{a}$ & $77 \mathrm{a}$ & 23.5 \\
$575 \mathrm{CL}$ & 6.8 & $6.34 \mathrm{~b}$ & $90 \mathrm{~b}$ & $4 \mathrm{~b}$ & $6 \mathrm{~b}$ & $79 \mathrm{~b}$ & $183.8 \mathrm{c}$ & $72 \mathrm{a}$ & 18.7 \\
\hline $\mathrm{F}$ & - & $375.2^{* *}$ & $26.1^{* *}$ & $20.8^{* *}$ & $21.3^{* *}$ & $41.2^{* *}$ & $39.7^{* *}$ & $5.3^{* *}$ & - \\
$\mathrm{CV}(\%)$ & - & 1.65 & 2.82 & 13.61 & 13.79 & 8.08 & 9.41 & 14.61 & - \\
\hline
\end{tabular}

${ }^{1}$ Means followed by the same letter in the column do not differ statistically from each other according to the Tukey test at 0.01 probability. ${ }^{2}$ The statistical procedure was performed with the data transformed into $(\mathrm{x}+1)^{1 / 2}$ and the means presented are from the original data. $\mathrm{CV}$ : coefficient of variation.

Table 2: Summary of the analysis of variance (Mean squares) of the data obtained in the emergence (E), first emergence count (FEC), speed of emergence index (SEI), abnormal seedlings (AS) and dead seeds (DS) of five canola hybrids using an alternative sowing method

\begin{tabular}{lcccccc}
\hline $\begin{array}{l}\text { Source } \\
\text { of variation }\end{array}$ & $\begin{array}{c}\text { Degrees } \\
\text { of freedom }\end{array}$ & E & FEC & SEI & AS & DS \\
\hline Hybrid $(\mathrm{H})$ & 4 & $18.2^{* *}$ & $74.7^{* *}$ & $64.4^{* *}$ & $7.6^{* *}$ & $21.3^{* *}$ \\
Treatment $(\mathrm{T})$ & 3 & $0.5^{\text {ns }}$ & $14.4^{* *}$ & $15.8^{* *}$ & $8.0^{* *}$ & $2.1^{\text {ns }}$ \\
H x T & 12 & $1.3^{\text {ns }}$ & $2.5^{* *}$ & $3.0^{* *}$ & $3.3^{* *}$ & $1.64^{\text {ns }}$ \\
\hline $\mathrm{CV}(\%)$ & 9.04 & 16.55 & 10.74 & 41.38 & 45.55 \\
\hline
\end{tabular}

**, ns: significant at $1 \%$ probability and not significant at $5 \%$ probability by $\mathrm{F}$ test, respectively. CV: coefficient of variation. 
methods where there was a barrier to emergence, more energy was spent on germination, and thus there were more abnormal seedlings as there was insufficient energy to create normal seedlings.

Seeds of the hybrid Hyola 575CL demonstrated the most vigor in the first count test, ranging from $59 \%$ to $73 \%$, regardless of the use of the tape or not (Table 5).

Seeds of the hybrid Hyola 50 had the lowest percentages for the first emergence count, which ranged from $15 \%$ to $31 \%$. Regardless of whether or not the tape was used, Hyola 50 did not differ from Hyola 61 seeds sown with the tape facing up, while seeds of hybrid 61 had intermediate results for the first emergence count when sown on side-facing tape as well as without tape (control).

It can be inferred that the two hybrids have seeds of lower vigor as they presented inferior performance. Vigorous seeds are known to influence the initial performance of the plants, providing a rapid and uniform emergence under a wide range of environmental variation (Marcos Filho, 2015), and, even where the tape was a barrier to emergence.

For the hybrid Hyola 571CL when the seeds were sown with the tape facing downwards there was a low emergence at the first count with $47 \%$. To circumvent the tape barrier the hypocotyl grows in a "U" shape, so the seed spends

Table 4: Abnormal seedlings (\%) of Hyola 433, Hyola 61, Hyola 571CL, Hyola 575CL and Hyola 50 canola hybrids using an alternative sowing method

\begin{tabular}{lcccc}
\hline & \multicolumn{4}{c}{ Sowing method } \\
\cline { 2 - 4 } Hybrids & Control & Down & Side & Up \\
\cline { 2 - 4 } & & Abnormal seedlings (\%) & $11 \mathrm{bcA}$ \\
Hyola 433 & $7 \mathrm{abA}$ & $8 \mathrm{aA}$ & $6 \mathrm{aA}$ & $18 \mathrm{cA}$ \\
Hyola 61 & $12 \mathrm{bA}$ & $14 \mathrm{abA}$ & $12 \mathrm{abA}$ & $3 \mathrm{aA}$ \\
Hyola 571CL & $3 \mathrm{aA}$ & $17 \mathrm{bB}$ & $5 \mathrm{aA}$ & $11 \mathrm{bcA}$ \\
Hyola 575CL & $7 \mathrm{abA}$ & $13 \mathrm{abA}$ & $8 \mathrm{abA}$ & $7 \mathrm{abA}$ \\
Hyola 50 & $7 \mathrm{abA}$ & $15 \mathrm{abB}$ & $14 \mathrm{bB}$ & $\mathrm{ab}$ \\
\hline
\end{tabular}

Means followed by the same lowercase letter in the column and upper case in the row do not differ statistically from each other according to the Tukey test at $1 \%$ probability.

Table 5: First emergence count (\%) of Hyola 433, Hyola 61, Hyola 571CL, Hyola 575CL and Hyola 50 canola hybrids using an alternative sowing method

\begin{tabular}{lcccc}
\hline Hybrids & \multicolumn{4}{c}{ Sowing method } \\
\cline { 2 - 4 } & Control & Down & Side & Up \\
\cline { 2 - 4 } & & First emergence count $(\%)$ & $74 \mathrm{aAB}$ \\
Hyola 433 & $74 \mathrm{abAB}$ & $59 \mathrm{aB}$ & $80 \mathrm{aA}$ & $49 \mathrm{bA}$ \\
Hyola 61 & $60 \mathrm{bA}$ & $52 \mathrm{aA}$ & $49 \mathrm{bA}$ & $82 \mathrm{aAB}$ \\
Hyola 571CL & $91 \mathrm{aA}$ & $47 \mathrm{aC}$ & $72 \mathrm{aB}$ & $73 \mathrm{aA}$ \\
Hyola 575CL & $72 \mathrm{abA}$ & $59 \mathrm{aA}$ & $71 \mathrm{aA}$ & $31 \mathrm{bA}$ \\
Hyola 50 & $25 \mathrm{cA}$ & $15 \mathrm{bA}$ & $26 \mathrm{cA}$ & \\
\hline
\end{tabular}

Means followed by the same lowercase letter in the column and upper case in the row do not differ statistically from each other according to the Tukey test at $1 \%$ probability.

Table 6: Speed of emergence index of Hyola 433, Hyola 61, Hyola 571CL, Hyola 575CL and Hyola 50 canola hybrids using an alternative sowing method

\begin{tabular}{lcccc}
\hline Hybrids & \multicolumn{4}{c}{ Sowing method } \\
\cline { 2 - 4 } & Control & Down & Side & Up \\
\cline { 2 - 4 } & & Speed of emergence index & $10.08 \mathrm{aAB}$ \\
\hline Hyola 433 & $10.55 \mathrm{bcA}$ & $8.55 \mathrm{aB}$ & $10.66 \mathrm{aA}$ & $8.00 \mathrm{bA}$ \\
Hyola 61 & $8.82 \mathrm{cA}$ & $8.15 \mathrm{aA}$ & $7.92 \mathrm{bA}$ & $11.09 \mathrm{aAB}$ \\
Hyola 571CL & $12.52 \mathrm{aA}$ & $7.80 \mathrm{aC}$ & $9.89 \mathrm{aB}$ & $11.17 \mathrm{aA}$ \\
Hyola 575CL & $11.07 \mathrm{abA}$ & $8.99 \mathrm{aB}$ & $11.36 \mathrm{aA}$ & $6.29 \mathrm{bA}$ \\
Hyola 50 & $5.97 \mathrm{dA}$ & $5.58 \mathrm{bA}$ & $5.99 \mathrm{bA}$ & \\
\hline
\end{tabular}

Means followed by the same lowercase letter in the column and upper case in the row do not differ statistically from each other according to the Tukey test at $1 \%$ probability. 
more energy reserves, decreasing the speed of emergence. It should be noted that this physical barrier did not affect the final emergence of the seedlings. It only had a greater impact in the first days after sowing, that is, at the beginning of the germination process and the emergence of the seedlings.

The speed of emergence ranged from 5.58 to 12.52 (Table 6). The sowing methods did not influence the speed of emergence of Hyola 61 hybrid seeds.

Hyola 61 and 575CL hybrids showed lower speed of emergence indices when sown without the tape. The speed of emergence did not differ for the 575CL hybrid when sown with the tape facing down compared to no tape. Seeds of the Hyola 571CL showed higher speed of emergence indices when sown without the tape or with the tape facing up.

The lowest speed of emergence indices of canola seedlings was seen in the hybrids Hyola 61 and Hyola 50 seeds. The speed at which the seeds germinate after sowing is of great importance for the satisfactory establishment of the seedlings in the field, as a delay in emergence can expose the seeds to unfavorable conditions, like an attack by pests and diseases, causing damage to the seeds and affecting performance (Estevez et al., 2012). Seeds with a lower speed of emergence produce a greater number of abnormal seedlings, which is an obvious sign of deterioration (Amirmoradi \& Feizi, 2017).

Regarding the percentage of dead seeds (Table 7), there was no interaction between the two factors. The hybrid Hyola 433 showed a lower percentage of dead seeds with 2\%, while Hyola 50, 61 and 571 showed no significant difference. Hyola 61 and 571 did not differ from Hyola 575CL.

Table 7: Dead seeds (\%) of canola hybrids Hyola 433, Hyola 61, Hyola 571CL, Hyola 575CL and Hyola 50

\begin{tabular}{lc}
\hline Hybrids & Dead seeds $(\boldsymbol{\%})$ \\
\hline Hyola 433 & $2 \mathrm{a}$ \\
Hyola 61 & $12 \mathrm{bc}$ \\
Hyola 571CL & $13 \mathrm{bc}$ \\
Hyola 575CL & $17 \mathrm{c}$ \\
Hyola 50 & $11 \mathrm{~b}$ \\
\hline
\end{tabular}

Means followed by the same letter do not differ statistically from each other according to the Tukey test at 0.01 probability.

\section{ACKNOWLEDGEMENTS, FINANCIAL SUPPORT AND FULL DISCLOSURE}

Thanks to Coordination of Improvement of Higher Education Personnel (CAPES), for granting the master degree scholarship - Financing Code 001.

There isn't any conflict of interests in carrying the research and publishing the manuscript.

\section{CONCLUSION}

The use of the adhesive tape did not interfere in the emergence of canola hybrids seedlings, with Hyola 571CL having the best performance while Hyola 50 and 61 showed inferior performances. In general, one should avoid the adhesive tape downwards facing.

\section{REFERENCES}

Amirmoradi S \& Feizi, H (2017) Can mean germination time predict seed vigor of canola (Brassica napus L.) seed lots? Acta Agrobotanica, 70:01-06.

Ávila MR, Braccini ADL, Scapim CA, Martorelli DT \& Albrecht LP (2005) Testes de laboratório em sementes de canola e a correlação com a emergência das plântulas em campo. Revista Brasileira de Sementes, 27:62-70.

Bhering LL (2017) Rbio: A tool for biometric and statistical analysis using the R platform. Crop Breeding and Applied Biotechnology, 17:187-190.

Brasil (2013) Instrução Normativa No 45, de 17 de Setembro de 2013. Padrões para a produção e a comercialização de sementes. DOU, 18/09/2013, Seção 01, p.09.

Brasil (2009) Ministério da Agricultura e da Reforma Agrária. Brasília, MAPA. 395p.

De Mori C, Tomm GO \& Ferreira PEP (2014) Aspectos econômicos e conjunturais da cultura da canola no mundo e no Brasil. Passo Fundo, Embrapa Trigo. 36p. (Boletim técnico, 149).

Estevez RL, Duarte Junior JB, Chambo APS, da Cruz MIF, Mrozinski CR \& Busanello M (2012) Características fisiológicas de sementes salvas (F2) de dois híbridos de canola cultivados em diferentes épocas de semeadura. Cultivando o saber, 05:133-142.

Koch F, Gehling VM, Pedó T, De Tunes LVM, Villela FA \& Aumonde TZ (2015) Expressão do vigor de sementes e desempenho inicial de plantas de canola: efeito da profundidade de semeadura. Revista de Agricultura, 90:193-201.

Maguire JD (1962) Spead of germination-aid in selection and evaluation for seedling emergence and vigour. Crop Science, 02:176-177

Marcos Filho J (2015) Fisiologia de sementes de plantas cultivadas. $2^{a}$ ed. Londrina, Abrates. 659p.

Marcos Filho J, Kryzanowski FC \& Vieira RD (1999) Teste de Envelhecimento Acelerado. In: França Neto JB (Ed.) Vigor de sementes: conceitos e testes. Londrina, Abrates. p.01-24.

Marcos Filho J (2015) Seed vigor testing: an overview of the past, present and future perspective. Scientia Agricola, 72:363-374.

Melgarejo Arruá AM, Duarte Júnior JB, Da Costa ACT, Mezzalira EJ, Piva AL \& Santin A (2014) Características agronômicas e teor de óleo da canola em função da época de semeadura. Revista Brasileira de Engenharia Agrícola e Ambiental, 18:934-938.

Milani M, Menezes NL \& Lopes SJ (2012) Teste de condutividade elétrica para avaliação do potencial fisiológico de sementes de canola. Revista Ceres, 59:374-379.

Nicolosi MM (2016) Desenvolvimento de método de semeadura em sistema de plantio direto para agricultura familiar. Tese de Doutorado. Universidade Estadual Paulista, Jaboticabal. 72p.

Pavlista AD, Santra DK, Isbell TA, Baltensperger DD, Hergert GW, Krall J, Mesbach, A, Johnson J, O’neil M, Aiken R \& Berrada A (2011) Adaptability of irrigated spring canola oil production to the US High Plains. Industrial Crops and Products, $33: 165-169$ 
Peske ST, Villela FA \& Meneghello GE (2012) Sementes: fundamentos científicos e tecnológicos. Pelotas, UFPel. 573p.

Shahin Y \& Valiollah R (2009) Effect of row spacing and seeding rates on some agronomical traits of spring canola (Brassica napus L.) cultivars. Journal of Central European Agriculture, 10:115-122.

Süzer S (2015) Effects of plant nutrition on canola (Brassica napus L.) growth. Trakya University Journal of Natural Sciences, 16:87-90

Tillmann MAA \& Menezes NL (2012) Análise De Seementes. In: Peske ST, Villela FA \& Meneghello GE (Eds.) Sementes: fundamentos científicos e tecnológicos. Pelotas, UFPel. p.161-268.

Tomm GO (2006) Canola: alternativa de renda e benefícios para os cultivos seguintes. Revista Plantio Direto, 15:04-08.

Tomm GO, Wiethölter S, Dalmago GA \& Santos HD (2009a) Tecnologia para produção de canola no Rio Grande do Sul. Passo Fundo, Embrapa Trigo. 41p. (Documentos online, 113).
Tomm GO, Ferreira PEP, de Aguiar JLP, de Castro AMG, Lima SMV \& de Mori C (2009b) Panorama atual e indicações para aumento de eficiência da produção de canola no Brasil. Passo Fundo, Embrapa Trigo. 27p. (Documentos online, 113).

Usda - United States Departament of Agriculture (2017) Economic Reserch Service Canola. Available at: <http://www.ers.usda.gov/ topics/crops/soybeans-oil-crops/canola.aspx>. Accessed on: June $26^{\text {th }}, 2017$.

Venkatesh R, Thomison PR, Gabriel CK, Bennett MA, Grassbaugh EM, Kleinhenz MD, Shearer SA \& Pitla S (2014) Seed tape effects on corn emergence under greenhouse conditions. Biological Systems Engineering: Papers and Publications, 13:0103

Vieira RD \& Carvalho NM (1994) Testes de vigor em sementes. Jaboticabal, Funep. 164p. 